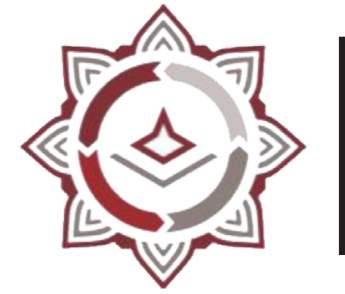

BISNIS: Jurnal Bisnis dan Manajemen Islam

P-ISSN: 2442-3718, E-ISSN: 2477-5533

Volume 9, Nomor 1, Juni 2021 (PP : 53-68)

https://journal.iainkudus.ac.id/index.php/Bisnis/index

http://dx.doi.org/10.21043/bisnis.v9i1.10310

\title{
Corporate Social Responsibility: Exxonmobil's form of Liability as a Foreign Investor of Mining Companies in Indonesia
}

\author{
Salsabila Fakhriyyah Ar Raidah \\ Universitas Negeri Semarang \\ salsabilafakh24@students.unnes.ac.id \\ Ekawati Rahayu Ningsih \\ Institut Agama Islam Negeri Kudus \\ ekawati@iainkudus.ac.id
}

\begin{abstract}
Currently, the business sector that is being intensified by the Indonesian government is the mining sector which is aimed at increasing state revenue. The state revenue aims to prosper the people's welfare, which is guaranteed by the constitution of Article 33 paragraph (3) of the 1945 Constitution of the Republic of Indonesia which states that the land, water and natural resources in it are state control designated in the event that prosperity of the people. In developing the mining business sector, Indonesia needs cooperation from foreign investors to adequately fulfill various needs. In developing the mining business sector, Indonesia needs cooperation from foreign investors to adequately fulfill various needs. In developing the mining business sector, Indonesia needs cooperation from foreign investors to adequately fulfill various needs. Therefore, Indonesia is cooperating with a company from America, namely PT. ExxonMobil. However, in the implementation of their investment activities, there are many problems, especially with the communities around the mining area. Therefore, this study aims to analyze the form of PT. ExxonMobil's responsibility for investing in Indonesia using normative juridical research methods..
\end{abstract}

Keywords: Investment, ExxonMobil, Mining. 


\section{INTRODUCTION}

It is undeniable that Indonesia is a country that has abundant natural resources. Where natural resources are very important for the survival of human life and living things on earth. Whether or not a natural resource is maintained will have a profound impact on living things on earth. There are several criteria if a thing can be categorized as natural resources, namely must meet the following criteria: 1) there is knowledge, technology, and skills to utilize its usefulness; and 2) there is required to be a request related to such natural resources. From these criteria, natural resources are production factors used in terms of providing goods and services in an economic activity.

There are two classifications of natural resources, namely non renewable (stock group) and renewable (flow group). Natural resources in the non- renewable classification are limited natural resources and cannot be renewed. Where this natural resource is formed from geological processes that take a very long time to be able to become natural resources that can be used. While the natural resources in the renewable classification is a renewable natural resource.

The management of non-renewable or non-renewable natural resources is in oil and gas mining. Which in this mining sector takes up to thousands to millions of years to form, considering that natural resources can not regenarasi. Therefore, companies engaged in oil mining must have the right decision to determine maximum oil production, and the estimated time for inventory should be extracted due to these limited inventory constraints. (Idris, 2013)

Because of the limited supply, the state must use the best because based on the mandate of the constitution Article 33 paragraph (2) of the Constitution of the Republic of Indonesia year 1945 (NRI Constitution 1945) has stated that the most important production branch for the state and control the life of the people is controlled by the state. The next article 33 paragraph (3) has been explained that the earth and water and any natural wealth contained in it, controlled by the state that will be used as much as possible for the prosperity of the people.

Based on the mandate of the constitution, it can be interpreted that the presence of the state in this case is as a mastery of the natural wealth that exists in the state of Indonesia, where the mastery should be solely intended to prosper and prosper 
the people. However, although the state's control over all natural resources should be used for the prosperity and welfare of the people, in reality it has not gone well.

The above is due to several things, namely the number of state politics on behalf of the public interest, the state, or development as a personal or group interest. In addition, in the substance of the law does not explain the meaning of "controlled" by the state, so there is a multi-interpretation that has implications on its application. Therefore, there is a conflict of authority and interest between sectoral government agencies in the utilization and use of natural resources in Indonesia. (Rokhim, 2017)

One of the various natural resources in Indonesia that are included in non renewable is in the oil and gas mining sector. Which in this sector is also one that is relied upon by the state in terms of increasing foreign exchange revenues for the development of the country. In terms of optimizing the management of oil and gas mining, Indonesia is represented by PT. Pertamina (Persero) cooperates with the United States represented by ExxonMobil Corporation in the Memorandum of Understanding (MoU) signed by The Minister of Economy Aburizal Bakrie of PT. Pertamina (Persero) and ExxonMobil on June 25, 2005, which was later confirmed through the Joint Operation Agreement (JOA). (Marwan Batubara, 2011)

ExxonMobil's presence in Indonesia is an activity to improve the economy through foreign investment or foreign investment by Multinational Corporation (MNC). Foreign investment is the most vigorous way to use because developing countries such as Indonesia consider that when there is foreign investment it will improve the country's economy easily, practically, and also quickly. (Mas'oed, 1997)

The management of oil and gas mining is carried out in Cepu, Blora Regency, or commonly known as Cepu Block. This mining production field is located in Banyu Urip, Alas Dara/Kemuninng, Jambaran, Sukowati, Cendana, and Alas Tua areas. At the end of 2008, the production process in cepu block was accelerated to increase production, investment, employment, gas utilization for industry, increase state revenue and also to develop society. The investment made in cepu block is up to

25 Trillion. Related to ExxonMobil supervision, conducted with a layered surveillance system from the government through pertamina intermediaries, BP Miigas, to BKP, BPK, KPK, Prosecutors to the Police. 
With the cooperation in terms of utilization of natural resources in this case is oil and gas, should be able to reap a good impact for improving the welfare and prosperity of the community around mining. In this case it is also in accordance with the obligation for every investor or investor who refers to Article 15 of Law No. 25 of 2007 concerning Investment which states that every investor is obliged to: 1) carry out the principles of good corporate governance; 2) carry out CSR activities; 3) make a report related to investment activities and submit it to bkpm institutions; 4) uphold the cultural traditions of the community around the company; and 5) comply with all statutory provisions of the. (Pasal 15 UndangUndang Nomor 25 Tahun 2007 tentang Penanaman Modal) In addition, Article 16 also states that the investor or investor in this case is ExxonMobil, must carry out its responsibility to maintain environmental sustainability.

However, ExxonMobil's presence has been a lot of problems, which since exxonmobil's operation in cepu block, came various reports related to environmental pollution conducted by ExxonMobil, including 1) citizen protests around oil wells stating that there are dead plants in rice fields that are suspected to be caused by hot flares (incendiary devices) ExxonMobil Cepu Limited (EMCL); 2) Bojonegoro District Environment Agency considers that ExxonMobil is less concerned about the surrounding environment so that it can cause air pollution; and 3) PT. Dwi Jaya Banyuurip as emcl partner suspected of environmental pollution. (Kertiyasa, 2018).

Based on the above, ExxonMobil's presence as a foreign investor or foreign investor in Indonesia, should with its investment activities in natural resource exploration can reap positive things that prosper and prosper the Indonesian people, especially the people who live around the company. However, with this report of alleged environmental pollution, it is questionable related to exxonmobil's legal responsibility and compliance as a foreign company that invests in Indonesia.

Therefore, in this paper, the Author will discuss two things, namely 1) ExxonMobil's Investment Form as a Foreign Investor of Mining Companies in Indonesia; and 2) ExxonMobil's Form of Accountability in Fulfilling Corporate Social Responsibility (CSR) as a Foreign Investor of Mining Companies in Indonesia. In discussing these two things, the author uses normative juridical research methods. Which in reviewing this issue is based on the norms that apply in 
a statutory regulation. Based on this, the Author will establish the main research focal point in Law No. 25 of 2007 on Investment and Law No. 40 of 2007 on Limited Liability Companies and other relevant laws and regulations.

\section{DISCUSSION}

\section{ExxonMobil Forms Investment as a Foreign Investor of Mining Companies in Indonesia}

Before entering a more concrete discussion, the author will explain that investment is a very familiar term used in business activities. But in legislation, this investment is called investment. However, both investments and investments have the same definition. (Halim, 2001) In Article 1 of Law No. 25 of 2007 concerning Investment (hereinafter referred to as the Investment Law), explains that investment is any form of activity related to investment, either domestic investment or foreign investment to conduct its business activities in the territory of Indonesia.

Salim HS defines investment as an investment business run by investors, both domestic and foreign investors for various business sectors that open to invest, which has the purpose to benefit. Investment activities have important elements as follows:

1) There is a motive to maintain or increase capital;

2) Capital obtained not only that can be touched and invisible, but also capital that can not be touched and invisible;

3) Investment has two types, as for foreign investment and domestic or domestic investment. Where foreign investment is financed from abroad, if domestic investment is an investment whose costs or capital are sourced from within the country.

The existence of this investment activity should be oriented to the welfare of the community. Which with investment should be able to improve the quality of every Indonesian. 
The development of the existence of investment or investment in Indonesia there are two periods, namely before independence and after the independence of Indonesia. This period before independence began in the 17 th and 18th centuries. This period was carried out by the Dutch government's policy of allowing foreign investors from Europe to enter Indonesia to invest in mining. (Roppke, 1986).

Then the post-independence period began with indonesia's independence in managing the country's economy with national development goals, although in terms of investment was still experiencing congestion due to dutch colonization accompanied by Japanese colonialism. Until 1949 after Indonesia gained recognition of sovereignty from the Netherlands, the condition of foreign investment was still jammed, where foreign investment was still running only inherited from the Dutch government. Then in 1953 the government drafted a Foreign Investment Law (PMA) designed for various minimum requirements while encouraging foreign investment in certain business sectors. However, this law is considered to restrict foreign investors to move some business sectors such as public service services and mining, but benefit domestic investors in some business sectors that are usually run by Indonesians themselves. (Muhaimin, 1990).

ExxonMobil has been running its business in Indonesia for approximately 120 years. There are so many achievements that have been achieved. By ExxonMobil companies in Indonesia (Mobil, 2021).

ExxonMobil itself has been a partner for more than 120 years that gained the trust of the Indonesian government in developing human resources, especially in the oil and gas sector that aims to provide economic standards for the people of Indonesia.

ExxonMobil company based in East Java has been cooperating with various other companies such as PT. Pertamina EP Cepu and the Cepu Block PI Cooperation Agency, which the cooperation aims to develop petroleum management in the Banyu Urip region. 
The region itself is under construction by several contractors whose leaders are Indonesian companies, involving 460 Subcontractors and Suppliers of Indonesia, in addition to being involved more than 17 thousand Indonesian workers who have contributed in the development stage.

Starting in 2007, ExxonMobil has provided training to more than 100 technician and maintenance operators who are residents with domiciles in East Java and Central Java. After training, the operators were placed in all ExxonMobil riots around the world, which would then be moved back to carry out their duties in the Banyu Urip Facility area. The Banyu Urip field has exceeded the original production plan of 165 thousand barrels per day and has exceeded its target of production of more than 210 thousand barrels per day, which is more than $25 \%$ of the national production target.

ExxonMobil then further demonstrates its existence by providing more roles to provide assistance in the fulfillment of energy needs in Indonesia. Pt. ExxonMobil Lubricants Indonesia (PT EMLI) is a company engaged in downstream business, chemicals, and fuel exxonmobil in Indonesia. PT EMLI conducts high quality lubricant marketing business under the car trademark with sales volume reaching more than 165 thousand barrels annually and has successfully entered the fuel market for industrial and commercial customers since 2016. Then continued in June 2018, PT. EMLI has made acquisitions of PT. Federal Karyatama (FKT) which is part of one of the largest suppliers and manufacturers of motor lubricants in Indonesia.

Acquisition made by PT. Emli includes the trademark Federal Oil and lubricant processing plant in Cilegon which has a production capability of $\mathrm{s}$ 700 thousand barrels annually. Federal Oil has the support of more than 40 distributors, 3200 Federal Oil centers and 10 thousand retailers throughout Indonesia. This acquisition complements car lubricant products for which ExxonMobil is highly experienced due to Federal Oil being an expert in motor lubricants. (Mobil, 2021)

As seen from its activities, ExxonMobil is very successful in this oil and gas business sector. ExxonMobil as an American company is a foreign investor or foreign investor who conducts investment activities that use foreign 
capital fully or cooperate with domestic investors. Based on this, ExxonMobil can be categorized in Foreign Direct Investment according to the type of investment seen from its capital source. (Hursepuny, 2019).

In this investment or investment there are other types that are according to the subject. Which investments according to the subject are personal invesman / investment or individual investments and public invesman / investment or state investment. This personal invesman uses his personal wealth to set up and run a business with the aim of gaining profit. Then the public invesman namely using state wealth to run a business by establishing state-owned enterprises (SOEs) and regionally owned enterprises (BUMD). (Hursepuny, 2019).

Based on the type of investment according to the subject, it can be interpreted that ExxonMobil is in the public invesman because of the presence of ExxonMobil in Indonesia through cooperation with the government through PT. Pertamina which in its businessactivities uses the country's natural resources.

The forms of investment consist of various kinds. If seen from the definition, a contract of work is cooperation between investors or investors from Indonesia and foreign investors or investors with the establishment of a legal entity in Indonesia, which then the legal entity makes a cooperation agreement with other legal entities that use national capital. Which, this form of investment is what ExxonMobil and the Government of Indonesia. (Hursepuny, 2019).

Based on the Investment Law, every investor or investor has an obligation one of which is to carry out corporate social responsibility. Then in the event of this responsibility, investors or investors in their investment activities must maintain environmental sustainability.

However, in reality ExxonMobil is considered to have not fulfilled its obligations and responsibilities as a foreign investor conducting investment activities in Indonesia. This is because many parties oppose exxonmobil's activities due to reports of environmental damage and pollution. (Kertiyasa, 2018). 
- Whether the investment activities are in accordance with the laws and regulations in Indonesia (rights and obligations in the Law)

- As a foreign investor exxonmobil is included in the PT, in the PT Law means Exxonmobil must meet environmental liability (CSR)

- Then proceed directly to the second discussion

\section{ExxonMobil's Form of Accountability in Fulfilling Corporate Social Responsibility (CSR) as a Foreign Investor of Mining Companies in Indonesia}

Based on the opinion of legal experts Saidi and Abidin, (Saidi,2004) companies in addition to having responsibilities related to the economic field to benefit each company also has other responsibilities in the form of legal, ethical, and philanthropic.

1) Economic responsibility. The purpose of the establishment of the company is to get the most profit. Profit is the main basis for the company in conducting its business, therefore economic objectives are used as an initial criterion so that the bias continues to progress and significant changes.

2) Legal liability. In order to obtain a large profit, the company is prohibited from violating various laws and regulations that have been made by the government.

3) Ethical responsibility. The Company has an obligation to conduct a variety of good, correct, and fair businesses. In addition to the laws and regulations that live in the community also need to be run by the company as a form of respect for the surrounding social environment.

4) Philanthropic responsibilities. The Company has the flexibility to profit, must also comply with various legal provisions and must act ethically. The company is strived in order to have a large impact that can directly affect the community. Itaims as an effort in improving the quality of life of human resources as well as the environment. 
From the four explanations above, it can be concluded that CSR is not only a mere charitable serimonial activity but also includes the giving of social donations by companies. The existence of CSR-related rules provides a necessity for companies to make internal decisions of the company by estimating clear targets, so as not to cause consequences for the surrounding environment.

The above is in line with the opinion of Syaifa Tania who stated that of the many companies that run their businesses in Indonesia, especially for oil and gas and mining businesses are ranked as a type of business that is very active in carrying out CSR activities. (Tania, 2012) One of the companies engaged in this sector is Exxonmobil.

As a mining company that has efforts to prosper the people, ExxonMobil is committed to community development programs through three main pillars, namely education, public health, and economic development. Since 2007, the company has invested US\$33 million which aims to implement various programs that have benefited more than 100,000 Indonesians.

The fact that bias occurs due to various activities of oil and gas companies and mining fields have a high risk of increased environmental damage that greatly impacts the activities of the community around the company.

The obligation to run CSR is not only an obligation for large companies such as Exxonmobik. Other companies also have similar burdens to carry out CSR obligations. Because basically every company that runs its business in Indonesia has a duty to provide support for the government in terms of improving the prosperity of its people.

Csr implementation obligations for every company including foreign companies are listed in the laws and regulations in Indonesia, which basically explains that every company has an obligation to carry out CSR policies.

The purpose of the rule is that corporate social responsibility is a responsibility that is integrated with the company, including foreign companies that set up their companies in Indonesia in order to form a sustainable connection and in harmony with the environment, values, norms, and culture that live in society. 
If the obligation is not carried out by the company, then it will be subject to administrative sanctions in the form of a written reprimand, limited company activities, temporary freeze, even the revocation of the company's license.

In addition to the provisions above, the obligation to implement CSR by the company can also be seen in Article 74 of the PT Law which regulates several things as follows:

1) Companies that conduct business activities in the field and related to human resources (natural resources must) have an obligation to carry out CSR, if then the company does not carry out the provision will be penalized.

2) The obligation as mentioned above is included as the cost of the company which in its implementation must be based on the principle of propriety or the principle of fairness.

Furthermore, Nunung Prajarto Together with Radityo M conducted mapping of CSR forms that have been run by several companies in Indonesia, among others as follows: (Prajarto, 2012) First, to develop Human Resources (SDA) by making donations in aspects such as scholarships, championship making, improving school facilities and infrastructure, providing training, and the latter in the field of sports starting from the preparatory stage, training athletes, as well as granting funds and improving sports facilities;

Second, improving welfare in economic aspects by providing initial capital for the community to be able to open businesses, conduct various forms of skills training, and foster good business relationships with the community;

Third, improving the welfare of the surrounding community by making efforts to improve its economy. This can be done by improving clean water facilities and infrastructure, providing medical assistance and improving public health facilities, and providing adequate transportation infrastructure;

Fourth, preserving the environment by increasing the number of trees to reforestation around the company's area and some locations that are often affected by floods, landslides, and droughts. This tree planting business is only one form of corporate concern to maintain the environment as an effort 
to reduce the greenhouse effect and green area arrangement. In addition, companies often also conduct CSR activities in the form of infrastructure development to process waste as an effort to prevent environmental pollution;

Fifth, provide a quick response in providing assistance to people who are experiencing natural disasters. Often companies also provide other assistance in the economic sector such as economic recovery to affected communities, until then seek better relocation of housing. Of the five forms of CSR can be concluded that CSR in Indonesia some programs are only designed for the short term only not for the long-term sustainability of the lives of the surrounding community. Most CSR is done for certain aspectssuch as education, health, and environmental preservation.

Meanwhile, the level of public satisfaction especially towards CSR conducted by ExxonMobil companies did not show good and positive results. Even often bring disappointment from the community on the part of the company, because of the lack of progress in the people of East Java after the company established in East Java. The implementation of the community continues to feel the continued loss until the public's trust in the programs from ExxonMobil disappears.

The program to develop for the community is called communitiy development (comdev), which is an obligation that must be carried out by mining management companies that are common in nature as a form of corporate social responsibility to the community around the corporate environment. Mining businesses such as Exxonmobil are accused by the community of causing adverse consequences for the environment. Although the company has benefited a lot from the SDA taken from the region. (Marwan Batubara, 2011).

Therefore, it is appropriate that the people around exxonmobil companies get various forms of compensation for the activities of companies run in their surroundings. This is because the surrounding community is getting a direct impact from various mining activities such as waste, environmental pollution, changes in the social environment of the community, and so forth. 
From the activities of comdev community in exxonmobil company should have benefited from various forms of CSR activities that have caused various negative impacts for the surrounding community. Because in fact the surrounding community actually has the right to enjoy the human resources in the region.

From various provisions governing and implementing CSR activities expressly the government relinquishes its responsibility for social and environmental issues by bestowing it on the company. If the company does not carry out csr obligations, which will then have an impact on the environment that is greatly harmed is the surrounding community.

While the purpose of human resources mastery is essentially to provide prosperity for all indonesian people. The association of the right of state control with the greatest for the prosperity of the people according to Bagir Manan in Abrar Saleng, will provide various state obligations, among others as follows: (Saleng, 2007)

1) All forms of utilization of human resources, must manifestly provide improvement of the standard of living of the community especially in the aspect of ecnomy so that the community is more prosperous;

2) Provide protection and guarantee of all rights related to the community in certain areas with abundant natural wealth, so that it can be felt and enjoyed directly by the surrounding community;

3) Provide a deterrent to all behaviors carried out by other parties that are likely to have a bad effect on the community, so that then the community does not get the opportunity or will even lose its right to feel the benefits of natural wealth in the surrounding area.

The implementation of CSR that can be done well by the company will have an impact on the creation of good investment climate conditions especially for foreign investors such as Exxonmobil. CSR is not something that provides obstacles for investors to invest their money in Indonesia. There is an obligation for all entrepreneurs who conduct their business in the territory of Indonesia to comply with all the provisions of the laws and regulations that have been established by, including for foreign investors. 
Natural resources are one of the important factors of Indonesia's superior bargaining when compared to other countries. It can be utilized properly if the government, private sector, and the public can prepare to improve the quality of infrastructure, human resources, and science and technology.

\section{CONCLUSION}

Legal provisions related to social liability (CSR) in Indonesia are influenced by the development of responsive law. The establishment of Law No. 40 of 2007 concerning Limited Liability Companies is a form of state responsibility to deal with the problems that occur from the establishment of various companies in Indonesia. Therefore, the government in the provisions of article 74 of Law No. 40 of

2007 concerning Limited Liability Companies regulates the matter. The establishment of such regulations in its implementation has not received good support from existing legal tools so that later in its implementation CSR arrangements can not be implemented properly. Including CSR run by Exxonmobil.

The author hopes that in the future, various probes that occur in the field can be handled well by the government. The government together with the relevant stake holders are expected to make a commitment so that the implementation of CSR can be carried out properly including the implementation of various sustainable programs in the long term. 


\section{References}

Abrar Saleng. Hukum Pertambangan.(Yogyakarta: UII Press,2007).

Andreas Halim. Kamus Lengkap 1Milyar Inggris-Indonesia. (Surabaya: Sulita Jaya).

Jochen Roppke. Kebebasan yang Terhambat; Perkembangan Ekonomi dan Perilaku Kegiatan Usaha di Indonesia. (Jakarta: Gramedia, 1986).

Marwan Batubara, dkk. Tragedi dan Ironi Blok Cepu Nasionalisme yang Tergadai. (Jakarta: IRESS, 2011). Mohtar Mas'oed, Perusahaan Multinasional Dalam Ekonomi-Politik Internasional, (Yogyakarta: Universitas Gadjah Mada, 1997).

Prajarto, Nunung dan M., Radityo. Lihatlah CSR-nya. (Yogyakarta: FISIPOL UGM, 2012).

Syafia Tania. Corporate Social Responsibility di Indonesia: Prinsip dan Aplikasi. (Yogyakarta: FISIPOL UGM, 2012).

Yahya A. Muhaimin. Bisnis dan Politik. (Jakarta: LP3ES, 1990).

Zaim Saidi dan Hamid Abidin. Menjadi Bangsa Pemurah: Wacana dan Praktek Kedewasaan Sosial di Indonesia. (Jakarta: Piramedia, 2004).

\section{Journals}

Abdul Rokhim. "Hubungan Kontraktual Antara Pemerintah dan Kontraktor Swasta Dalam Kontrak Pertambangan Minyak dan Gas Bumi”. Jurnal Rechtidee, Vol. 12, No. 1, (Juni 2017): 28.

Amiruddin Idris. "Pengelolaan Sumberdaya Tidak Pulih Berbasis Ekonomi Sumberdaya (Studi Kasus: PT. ARUN NGL)". Jurnal Lentera, Vol. 13, No. 4, (Nopember 2013): 2-3. 
Johan Hursepuny. "Penanaman Modal dan Permasalahannya di Indonesia”. Journal of Information System, Applied, Management, Accountingm and Research, Vol. 3, No. 2, (Mei 2019): 74.

Wandha Lucia Kertiyasa. "Peran MNC Mencegah Pencemaran Lingkungan: Studi Kasus ExxonMobil di Blok Cepu". Journal of International Relations, Vol. 4, No. 4, (2018): 851.

\section{Regilation}

Law Number 25, 2007 about investment

\section{Online Article}

ExxonMobil.co.id. “Tentang Kami”. https://www.exxonmobil.co.id/id- $\underline{I D /}$

Company/Overview/Who-we- are/About-us, diakses pada tanggal 1 April 2021. 